\title{
Helminths infecting the cat-eyed snake Leptodeira annulata Linnaeus 1758 (Squamata: Dipsadidae) in a semiarid region of Brazil
}

\author{
E. F. FERNANDES DE CARVALHO"*, A. FERREIRA DA SILVA-NETA², C. DE SOUSA SILVA², C. R. DE OLIVEIRA², \\ J. DA CUNHA XAVIER NUNES ${ }^{2}$, T. GONÇALVES DE SOUZA', R. W. ÁVILA',2
}

\begin{abstract}
'Programa de Pós-Graduação em Ecologia e Recursos Naturais, Departamento de Ciências Biológicas, Universidade Federal do Ceará, Campus Universitário do Pici, CEP 60021970, Fortaleza, Ceará, Brasil, " EE-mail: elvis_ffc@hotmail.com; ²Programa de PósGraduação em Bioprospecção Molecular PPBM, Departamento de Química Biológica, Universidade Regional do Cariri, Ceará, Campus Pimenta, CEP 63105-000, Crato, Ceará, Brasil
\end{abstract}

\section{Article info}

Received March 1, 2018 Accepted July 3, 2018

\begin{abstract}
Summary
Snakes have diverse feeding and living habits, being exposed to a variety of endoparasite communities. However, more studies are still necessary to document these relationships. We examined 18 specimens of the cat-eyed snake Leptodeira annulata from a semi-arid region in Northeast Brazil. Eight taxa of parasites were found, with higher prevalence of cystacanths (Acanthocephala). Five nematode species (Hexametra boddaertii, Oswaldocruzia sp., Oxyascaris sp., Physaloptera sp. and Raillietnema spectans) and the pentastome Raillietiella furcocerca represent a new parasitism record for the host studied. Our results also showed that $L$. annulata could act as paratenic host for acanthocephalans. These results contribute to the knowledge of the helminth fauna of $L$. annulata. Keywords: parasites, nematoda, neotropical, Pentastomida, snakes, reptiles
\end{abstract}

\section{Introduction}

Parasitism is one of the most common life styles with parasites representing a considerable portion of the world's biomass, but these organisms were for a long time neglected in biodiversity surveys (Poulin \& Morand, 2004; Dobson et al., 2008; Kuris, 2008). Given the importance of these organisms structuring communities in ecosystems, as well provide data on ecology of the host (Poulin, 1999; Brooks \& Hoberg, 2000), there has been a recent increase of studies on the fauna of endoparasites especially of reptiles in Brazil (Anjos et al., 2011; Albuquerque et al., 2012; Ávila et al., 2012; Teles et al., 2015). Such studies provide information about the ecology, natural history, life cycle, and evolution of host-parasite systems. However, the lack of studies on helminths associated with vertebrate organisms is still evident, being necessary more studies in the area (Mati et al., 2015).

The endoparasite fauna can be related, among other factors, to the diet and microhabitat of hosts (Brito et al., 2014; Ribas et al.,
1998). Snakes have very diverse feeding habits, being exposed to a wide variety of parasites (Aho, 1990; Jiménez-Ruiz, et al., 2002). Leptodeira annulata (Linnaeus 1758) is a semi-arboreal reptile, distributed from Mexico to eastern of South America (Duellman, 1958) and along all biomes of Brazil, such as the Amazon, Atlantic forest, Cerrado, and Caatinga (Bertoluci et al., 2009; Bernarde et al., 2012; Cole, et al., 2013; Mesquita et al., 2013). Studies on L. annulata address aspects like foraging, diet and reproduction (Martins \& Oliveira, 1998; Mesquita et al., 2013; Silva-Neta et al., 2015), but data on the parasitic fauna are scarce with records only Ophidascaris trichuriformis Vaz, 1935 (Sprent, 1988) and Renifer heterocoelium Travassos, 1921 (Pinto et al., 2012).

In this context, species inventory are important tools serving as a base for ecological studies, enabling the knowledge of what and how many species are part of an ecosystem and providing essential information about the diversity of organisms (Poulin et al. 2015). Aiming at filling the gap in the knowledge of the parasite fauna of $L$. annulata, this study analyzed the helminth fauna as-

\footnotetext{
$\bar{*}$ - corresponding author
} 
sociated with individuals from the Southern region of Ceará State, Brazil.

\section{Material and Methods}

This study was carried out with samples from the Herpetological Collection of Universidade Regional do Cariri (URCA-H- 1981; 3279; 4532; 4907; 4910; 4911; 4913; 4914; 4915; 5541; 5631; $6742 ; 6847 ; 7521 ; 7889 ; 7900 ; 8014 ; 11228)$. The specimens were collected from 2012 to 2014 in the municipality of Aiuaba $(n=4)$

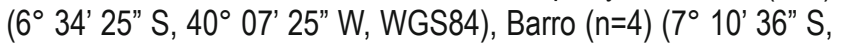
$38^{\circ} 46^{\prime} 54^{\prime \prime}$ W, WGS84), Farias Brito (n=8) (6 $55^{\prime} 50^{\prime \prime} \mathrm{S}, 39^{\circ} 33^{\prime}$ $56^{\prime \prime}$ W, WGS84), Jati ( $\left.n=1\right)\left(7^{\circ} 41^{\prime} 10^{\prime \prime} \mathrm{S}, 39^{\circ} 00^{\prime} 57^{\prime \prime} \mathrm{W}\right.$, WGS84) and Mauriti ( $n=1)\left(7^{\circ} 23^{\prime} 21^{\prime \prime} \mathrm{S}, 38^{\circ} 46^{\prime} 28^{\prime \prime}\right.$ W, WGS84) all located in the Southern region of Ceará State, Brazil (Fig. 1). Study area is characterized by hot semi-arid tropical climate and mild hot semi-arid tropical climate (IPECE, 2016).

A total of 18 specimens of $L$. annulata being eight females (mean snout-vent length $541.2 \mathrm{~mm}$ ) and eleven males (447.5 mm SVL) were euthanized with a lethal injection of sodium thiopental (CFMV, 2013) necropsied and had the liver, lung, heart, mouth, larynx, stomach, large and small intestine, coelomic cavity, and kidneys checked for presence of parasites under the stereomicroscope. The parasites found were processed to separate them completely from the host tissue and stored in $70 \%$ ethanol.
Aiming to perform the taxonomic identification of the helminths obtained, different preparation methods were carried out according to the taxonomic group. Cystacanths were, stained with carmine and preserved in $70 \%$ ethanol. The cestode was also stained with carmine and fixed between slide and coverslip. The nematodes were mounted in temporary slides with Amman's lactophenol or latic acid. The pentastomes were cleared using Hoyer's solution and preserved in $70 \%$ ethanol. The slides were examined with optical microscope and the specimens were identified using the keys for identification of Yamaguti $(1959,1961,1963)$, Vicente et al. (1993), Gibbons (2010), Rego (1983). Samples of all parasites were deposited in the Helminthological Collection of the laboratory of Zoology of Universidade Regional do Cariri, URCA, Ceará State, Brazil.

The parasitological descriptors of prevalence $(P)$, mean abundance (MA), mean intensity of infection (MII), richness, and range of intensity of infection (RII) were calculated according to Bush et al. (1997).

\section{Ethical Approval and/or Informed Consent}

The collection of specimens was authorized by Instituto Chico Mendes de Conservação da Biodiversidade-ICMBio (Authorization number 29613-1) and by the ethics committee of Universidade Regional do Cariri (CEUA/URCA, process No. 00260/2016.1), the

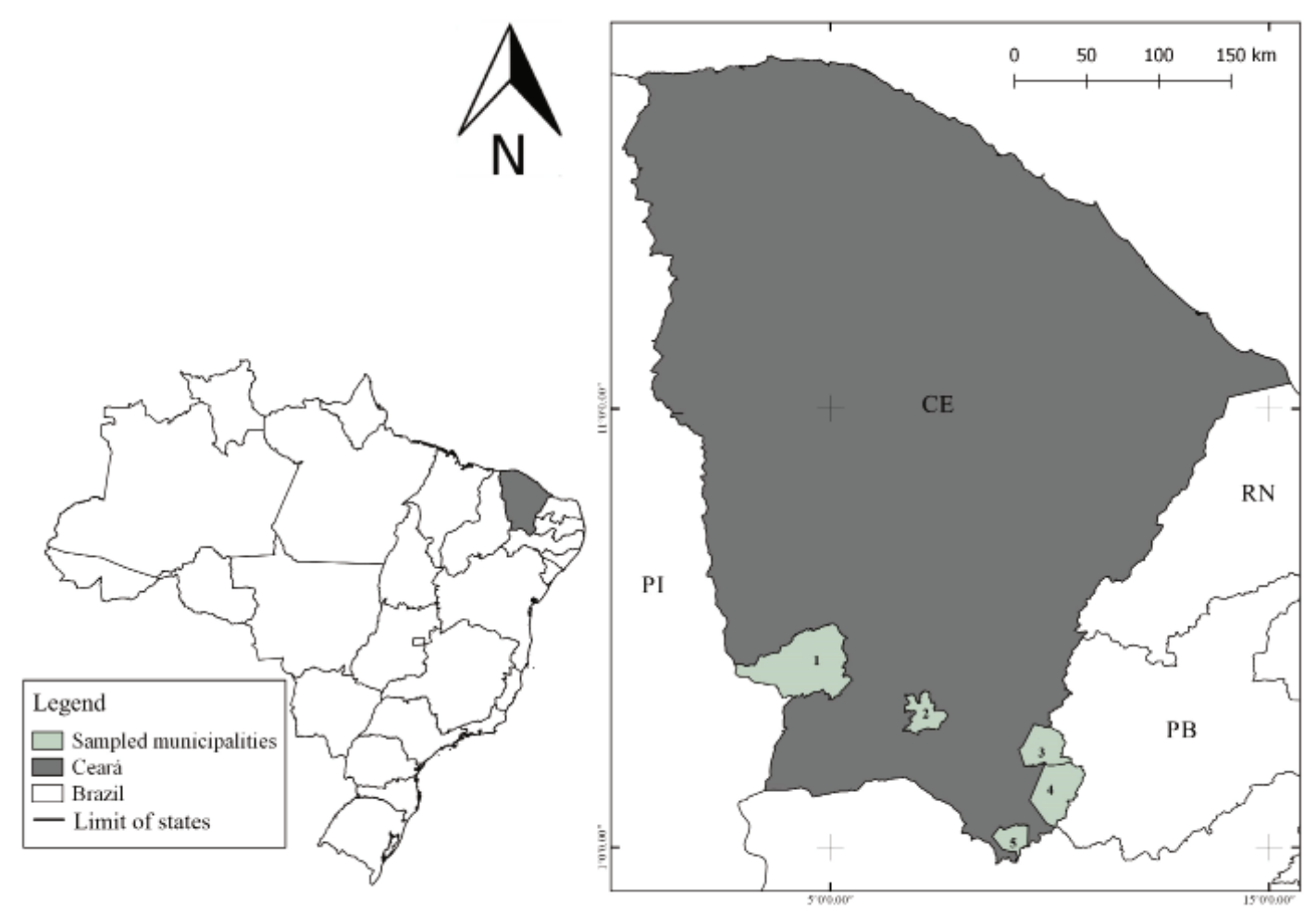

Fig. 1 Municipalities where the specimens of Leptodeira annulata were collected in the state of Ceará, Brazil. 1-Aiuaba, 2-Farias Brito, 3- Barro, 4- Mauriti, 5- Jati. 
research related to animals has been complied with all the relevant national regulations and institutional policies for the care and use of animals.

\section{Results}

A total of 153 parasite specimens were collected with total prevalence of $78.9 \%$ and mean intensity of infection of $10.20 \pm 2.81$. The component community associated with $L$. annulata was composed of eight taxa: 18 specimens of nematodes distributed in five taxa (Hexametra boddaertii Baird 1860, Raillietnema spectans Gomes 1964, Oswaldocruzia sp., Oxyascaris sp., and Physaloptera sp.), three pentastomes of the species Raillitiella furcocerca Diesing, 1863, one unidentified cestode, and 131 unidentified cystacanths (Acanthocephala) (Table 1). The cystacanths showed the highest prevalence (63.2\%), intensity (10.92 \pm 3.28$)$, and mean abundance (6.9). The cysts could not be identified at species level because the shape and number of the hooks in the proboscis could not be determined. The cestode was found in one female host specimen (SVL $=544.36)$, showing the lowest values of prevalence (5\%), intensity (1), and mean abundance (0.05), but the parasite specimen could not be identified at species level due to poor conditions of preservation.

\section{Discussion}

Studies that investigated the helminth fauna of some snake species from the Neotropical region such as McAllister et al. (2010a, 2010b), Bursey and Brooks (2011) did not record any infection in $L$. annulata. This fact may be due to the low number of individuals studied, because in the present study, $L$. annulata presented higher richness (8 parasite taxa) compared to studies of endoparasites for other snake species (Ávila et al., 2013; Nasiri et al., 2014).
Raillietnema spectans is a common parasite in amphibians (Vicente et al., 1990). The low prevalence of this parasite in the snake $L$. annulata could represent an accidental infection, since this nematode have a monoxenic life cycle and infection occurs through ingestion of eggs and/or larvae penetrating actively in host skin (Anderson, 2000). Leptodeira annulata is an active forager feeding mainly on amphibians (Martins \& Oliveira, 1998; Bernarde \& Abe, 2010; Mesquita et al., 2013) and could be exposed to this parasite while foraging.

The unidentified species of Acanthocephala found in this study showed the highest prevalence and were present in the coelomic cavity of 12 specimens of $L$. annulata. Similar results were found by Smales (2007) in nine colubrid species which also presented acanthocephalans encysted in coelomic cavity. The presence of cystacanths in the coelomic cavity of the snakes analyzed indicates that they are acting as paratenic hosts. The cysts were probably acquired from amphibians that are part of the diet of $L$. annulata (Mesquita et al. 2013). According to Baker (2007), acanthocephalans have indirect life cycle, with intermediate forms in arthropods and crustaceans, reaching their adult stage in fish or aquatic birds. In the case of infecting an unsuitable host, the parasites can encyst again until reaching a definite host.

The correct identification of the acanthocephalans found in the present study was not possible due to encysted form of the specimens which prevents the visualization of morphological characteristics necessary for identification, such as proboscis rows of hooks and reproductive organs (Smales, 2007).

The pentastome $R$. furcocerca belongs to a parasite genus commonly found in the respiratory system of squamates from South America (Almeida et al., 2008a). This parasite is known to infect snakes with Neotropical distribution, being already recorded in Boa constrictor (Linnaeus, 1758), Clelia clelia (Daudin, 1803), Crotalus durissus (Linnaeus, 1758), Drymarchon corais (Boie, 1827),

Table 1. Prevalence (P), mean intensity of infection (MII) with standard error (SE), (MA) mean abundance, (IS) infection site, and (RII) range of intensity of infection of the helminths associated with the snake Leptodeira annulata from the South region of Ceará State, Brazil.

\begin{tabular}{lccccc}
\hline & $\mathrm{P}(\%)$ & $\mathrm{MII} \pm \mathrm{SE}$ & $\mathrm{MA}$ & $\mathrm{IS}$ & $\mathrm{R}$ \\
\hline $\begin{array}{l}\text { Acanthocephala } \\
\text { Cystacanth }\end{array}$ & 66.7 & $10.92 \pm 3.28$ & 7.28 & $\mathrm{BC}$ & $2-37$ \\
$\begin{array}{l}\text { Cestoda } \\
\text { Unidentified cestode }\end{array}$ & 5.6 & 1 & 0.05 & $\mathrm{SI}$ & $1-1$ \\
$\begin{array}{l}\text { Nematoda } \\
\text { Hexametra boddaertii }\end{array}$ & 5.6 & 1 & 0.05 & $\mathrm{~L}$ & $1-1$ \\
$\begin{array}{l}\text { Oswaldocruzia sp. } \\
\text { Oxyascaris sp. }\end{array}$ & 5.6 & 2 & 0.11 & $\mathrm{LI}$ & $1-2$ \\
$\begin{array}{l}\text { Physaloptera sp. } \\
\text { Raillietnema spectans }\end{array}$ & 5.6 & 2 & 0.11 & $\mathrm{SI}$ & $1-2$ \\
$\begin{array}{l}\text { Pentastomida } \\
\text { Raillitiella furcocerca }\end{array}$ & 5.6 & 1 & 0.11 & $\mathrm{ST}$ & $1-2$ \\
\hline
\end{tabular}

Infection sites: body cavity (BC), large intestine (LI), small intestine (SI), stomach (ST), lung (L). 
Lachesis sp. (Motta, 1963; Rego, 1983) Mastigodryas bifossatus (Raddi, 1820), Philodryas nattereri (Steindachner, 1870), Pseudoboa nigra (Duméril, Bibron and Duméril, 1854), Thamnodynastes chaquensis (Bergna and Alvarez, 1993), Thamnodynastes chaquensis (Bergna and Alvarez, 1993), Thamnodynastes chaquensis (Bergna and Alvarez, 1993), Xenodon merremii (Wagler, 1824), (Alcantara et al., 2014; Almeida et al., 2008b; Esslinger, 1986). The present study represents the first record of $R$. furcocerca infecting $L$. annulata.

This study presents new records for the nematodes $H$. boddaertii, Oswaldocruzia sp., Oxyascaris sp. and $R$. spectans in L. annulata, the first record of a cestode in $L$. annulata, and the first record of infection by the pentastome $R$. furcocerca in this snake species. These records have the importance of being part of the first studies for the Caatinga area in Northeast of Brazil with this species, and also contribute significantly to the knowledge of the parasitic fauna of $L$. annulata in the Neotropical region providing data on the helminths associated with this snake species.

\section{Acknowledgements}

To Conselho Nacional de Desenvolvimento Científico e Tecnológico (CNPq) for financial support (process 551993/2011-1) and providing a research fellowship to RWA (\# 303622/2015-6); and the Fundação Cearense de Apoio ao Desenvolvimento Científico e Tecnológico (FUNCAP) for providing a Master fellowship to EFFC, CSS, AFSN and CRO. We also thank the editor and the anonymous reviewers for the valuable suggestions on the manuscript.

\section{Conflict of interest}

Authors state no conflict of interest.

\section{References}

AHO, J.M. (1990): Helminth communities of amphibians and reptiles: comparative approaches to understanding patterns and processes. In: Esch, G.W., Bush, A.O., Aно, J.M. (Eds) Parasite Communities: Patterns and Processes. Springer, Dordrecht, pp. $157-195$

Albuquerque, S., Ávila, R.W., Bernarde, P.S. (2012): Occurrence of Helminths in Lizards (Reptilia: Squamata) at Lower Moa River Forest, Cruzeiro do Sul, Acre, Brazil. Comp. Parasitol., 79: 64 67. DOI: $10.1654 / 4539.1$

Alcantara, E.P., Ferreira-Silva, C., Ávila, R.W., Oliveira, W.A. (2014): Pseudoboa nigra (Black False Boa) Endoparasites. Herpetol. Rev., 45(2):343 - 343

Almeida, W., Freire, E., Lopes, S. (2008a): A new species of pentastomida infecting Tropidurus hispidus (Squamata: Tropiduridae) from Caatinga in Northeastern. Braz. J. Biol., 68(1): 199 - 203. DOI: 10.1590/S1519-69842008000100029

Almeida, W.O., Guedes, T.B., Freire, E.M.X., Vasconcellos, A. (2008b): Pentastomid infection in Philodryas nattereri Steindachner, 1870 and Oxybelis aeneus (Wagler, 1824) (Squamata: Colubridae) in a Caatinga of northeastern Brazil. Braz. J. Biol., 68(1): 193 - 197. DOI: 10.1590/S1519-69842008000200028

Anderson, R.C. (2000): Nematode Parasites of Vertebrates, their Development and Transmission. $2^{\text {nd }}$ Edition, Walingford, UK, CABI Publishing, $650 \mathrm{pp}$.

Anjos, A.L. Holanda, B.C., Cunha-Passos, D., Zanchi, D., Galdino, B., Aleksander, C. (2011): Helminth Fauna of Two Gecko Lizards, Hemidactylus agrius and Lygodactylus klugei (Gekkonidade), From Caatinga Biome, Northeastern Brazil. Neotrop. Helminthol., 5(2): $285-290$

Ávila, R., Morais, D., Anjos, L., Almeida, W., Silva, R. (2013): Endoparasites infecting the semiaquatic coral snake Micrurus surinamensis (Squamata: Elapidae) in the southern amazonian region, Mato Grosso state, Brazil. Braz. J. Biol., 73(3): 645 - 647. DOI: 10.1590/s1519-69842013000300024

Ávila, R.W., Anjos, L. A., RibeiRo, S. C., Morals, D.H., Silva, R.J., Almeida, W.O. (2012): Nematodes of lizards (Reptilia: Squamata) from Caatinga biome, northeastern Brazil. Comp. Parasitol., 79(1): 56 - 63. DOI: 10.1645/16-69

BAKER, D.G. (2007): Acanthocephala in: Flynn's Parasites of Laboratory Animals: Second Edition. Oxford, UK: Blackwell Publishing Ltd, pp. 193

Bernarde, P.S., Abe, A.S. (2010): Hábitos alimentares de serpentes em Espigão do Oeste, Rondônia, Brasil [Feeding habits of snakes in Espigão do Oeste, Rondôndia, Brazil]. Biota Neotrop., 10(1): 164 - 173 (In Portuguese)

Bernarde, P.S., De Albuquerque, S., Barros, T.O., Turci, L.C.B. (2012): Serpentes do estado de Rondônia, Brasil [Snakes of Rondônia State, Brazil]. Biota Neotrop., 12(3): 1 - 29 (In Portuguese) Bertoluci, J., Canelas, M.A.S., Eisemberg, C.C., Palmuti, C.F.D.S., MontingelLI, G.G. (2009): Herpetofauna of Estação Ambiental de Peti, an Atlantic Rainforest fragment of Minas Gerais State, southeastern Brazil. Biota Neotrop., 9(1): 147 - 155

Brito, S.V., Corso, G., Almeida, A.M., Ferreira, F.S., Almeida, W.O., Anjos, L.A., Vasconcellos, A. (2014): Phylogeny and micro-habitats utilized by lizards determine the composition of their endoparasites in the semiarid Caatinga of Northeast Brazil. Parasitol. Res., 113(11): 3963 - 3972. DOI: 10.1007/s00436-014-4061-z

BRooks, D.R., Hoberg., E.P. (2000): Triage for the Biosphere: The Need and Rationale for Taxonomic Inventories and Phylogenetic Studies of Parasites. Comp. Parasitol. 67(1): 1 - 25

BuRsey, C.R., BRooks, D.R. (2011): Nematode Parasites of Costa Rican Snakes (Serpentes) with Description of a New Species of Abbreviata (Physalopteridae). Comp. Parasitol. 78(2): 333 - 358. DOI: $10.1654 / 4495.1$

Bush, A.O., Lafferty, K.D., Lotz, J.M., Shostak, A.W. (1997): Parasitology Meets Ecology On Its Own Terms: Margolis et Al. Revisited. J. Parasitol. 83: 575 - 583. DOI: 10.2307/3284227

CFMV. Conselho Federal de Medicina Veterinária. (2013): Métodos de eutanásia. In: Guia brasileiro de boas paráticas de eutanásia 
em animais, pp. 28 - 29. Comissão de ética, Bioética e bem-estar animal. Brasília, Distrito Federal. [CFMV. Federal council of veterinary medicine. (2013) Methods of euthanasia. In: Brazilian guide to good euthanasia pratices in animals, pp 28 - 29. Ethics committee and animal welfare. Brasília, Federal District] (In Portuguese) Dobson, A., Lafferty, K.D., Kuris, A.M., Hechinger, R.F., Jetz, W. (2008): Homage to Linnaeus: How many parasites? How many hosts. Proc. Natl. Acad. Sci. 105(Supplement 1): 11482 - 11489. DOI: 10.1073/pnas.0803232105

Duellman, W.E. (1958): A monographic study of the Colubrid snake genus Leptodeira. Bullet Am Mus Nat Hist., 114, 1 - 183

EssLinger, J.H. (1986): Morphology of the Egg and Larva of Raillietiella furcocerca (Pentastomida) from a Colombian snake (Clelia clelia) ${ }^{*}$. J. parasitol., 54(2): 411 - 416. DOI: 10.2307/3276962

GibBons, L. (2010): Keys to the Nematode Parasites of Vertebrates. Supplementary Volume. CAB International, Wallingford, U.K, 416 pp.

IPECE-Instituto de Pesquisa e Estratégia Econômica do Ceará. (2017): Perfil municipal 2016 [IPECE- Institute of research and economic strategy of Ceará. (2017): Municipal profile 2016] Retrieved October 10, 2017 from <http://www.ipece.ce.gov.br/index. php/2016-12-16-13-09-40> (In Portuguese)

Jiménez-Ruiz, F.A., Garcia-Prieto, L., Pérez-Ponce de León, G. (2002): Helminth infracommunity structure of the sympatric garter snakes Thamnophis eques and Thamnophis melanogaster from the Mesa Central of Mexico. J. Parasitol., 88(3): 454 - 460. DOI: doi.org/10.1645/0022-3395(2002)088[0454:HISOTS]2.0.CO;2

KURIS, A.M. (2008): Ecosystem energetic implications of parasite and free-living biomass in three estuaries. Nature, 454(7203): 515 - 518. DOI: 10.1038/nature06970

MARTINS, M., OliveIRA, M.E. (1998): Natural history of snakes in forests of the Manaus region, central Amazonia, Brazil. Herpetol. Nat. Hist., 6(2): 78 - 150

Mati, V.L.T., Pinto, H.A., Melo, A.L. (2015): Helminths of Liophis miliaris (Squamata, Dipsadidae): a list of species and new records. Helminthologia, 52(2): 159 - 166. DOI: 10.1515/helmin-2015-0029 Mcallister, C.T., Bursey, C.R., Freed, P.S. (2010a): Helminth Parasites of Selected Amphibians and Reptiles from the Republic of Ecuador. Comp. Parasitol., 77(1): 52 - 66. DOI: 10.1654/4402.1

Mcallister, C.T., Bursey, C.R., Freed, P.S. (2010b): Helminth Parasites (Cestoidea: Nematoda) of Select Herpetofauna from Paraguay. J. Parasitol., 96(1): 222 - 224. DOI: 10.1645/GE-2191.1 Mesquita, P.C.M.D., Passos, D.C., Borges-Nojosa, D., Cechin, Z. (2013): Ecologia e história natural das serpentes de uma área de Caatinga no nordeste brasileiro [Ecology and natural history of snakes from an area of caatinga in northestean Brazil]. Pap avulsos de Zool. 53(8): 99 - 113. DOI: 10.1590/S003110492013000800001 (In Portuguese)

Nasiri, V., Mobedi, I., Dalimi, A., Mirakabadi, A.Z., Ghaffarifar, F.,
Teymurzadeh, S., Karimi, G., Abdoli, A., Paykari, H. (2014): A description of parasites from Iranian snakes. Exp. Parasitol., 147: 7 - 15. DOI: 10.1016/j.exppara.2014.09.007

Pinto, H.A., Mati, V.L.T., De Melo, A.L. (2012): New hosts and localities for trematodes of snakes (reptilia: Squamata) from Minas Gerais State, southeastern Brazil. Comp. Parasitol., 79(2): 238 246. DOI: $10.1654 / 4548.1$

Poulin, R. (1999): The functional importance of parasites in animal communities: Many roles at many levels? Int. J. Parasitol., 29(6): 903 - 914. DOI: 10.1016/S0020-7519(99)00045-4

Poulin, R., Besson, A.A., Morin, M.B., Randhawa, H.S. (2015): Missing links: testing the completeness of host-parasite checklists. Parasitol. 143(1): 114 - 122. DOI: 10.1017/S0031182015001559

Poulin, R., Morand, S. (2004): Parasite Biodiversity, Smithsonian Institution Books, Washington, D.C., USA. pp. 216

Rego, A.A. (1983): Pentastomídeos de répteis do Brasil: Revisão dos Cephalobaenidae [Reptiles Pentastomids of Brazil: Review of Cephalobaenidae]. Mem. Inst. Oswaldo Cruz, 78 (4): 399 - 411 (In Portuguese)

Ribas, S.C., Rocha, C.F.D., Teixeira-Filho, P.F., Vicente, J.J. (1998): Nematode infection in two sympatric lizards (Tropidurus torquatus and Ameiva ameiva) with different foraging tactics. Amphib-Reptil., 19(3): 323 - 330. DOI: 10.1163/156853898X00232

Silva-NetA, A.F., Claudio, M.S., Ávila, R.W. (2015): Leptodeira annulata (banded cat- eyed). Diet. Herpetol. Rev., 46(3): 452 - 452. SMALES, L.R. (2007): Acanthocephala in amphibians (Anura) and reptiles (Squamata) from Brazil and Paraguay with description of a new species. J. Parasitol., 93(2): 392 - 398. DOI: 10.1645/GE937R.1

SPRENT, J.F.A. (1988) Ascaridoid nematodes of amphibians and reptiles: Ophidascaris Baylis, 1920. Syst. Parasit.11: $165-213$

Teles, D.A., Sousa, J.G.G., Teixeira, A.A.M., Silva, M.C., Oliveira, R.H., SILVA, M.R.M., ÁvILA, R.W. (2015): Helminths of the frog Pleurodema diplolister (Anura, Leiuperidae) from the Caatingain Pernambuco State, Northeast Brazil. Braz. J. Biol., 75(1): 251 - 253. DOI: 10.1590 / 1519-6984.08513

Vicente, J.J., Rodrigues, H.D.O., Gomes, D.C., Pinto, R.M. (1991): Nematóides do Brasil 2a parte: Nematóides de anfíbios. Rev. Bras. Zool., 7(4): 549 - 626. DOI: 10.1590/S0101-81751990000400015 Vicente, J.J., Rodrigues, H.O., Gomes, D.C., Pinto, R.M. (1993): Nematóides do Brasil. Parte III: Nematóides de répteis. Rev. Bras. Zool., 10(1): 19 - 168. DOI: 10.1590/S0101-81751993000100003 Yamaguti, S. (1959): Systema Helminthum - Cestodes. vol. 2, Interscience Pub., London, pp. 860

Yamaguti, S. (1961): Systema Helminthum - Nematodes. vol. 3, Interscience Pub., London, part I and II, pp. 697

Yamaguti, S. (1963): Systema Helminthum - Acanthocephalans. v. 4, Interscience Pub., London, pp. 1074 